\title{
Growing Season and Phenological Stages of Small Grain Crops in Response to Climate Change in Alaska
}

\author{
Mingyuan Cheng1, Mingchu Zhang1 ${ }^{*}$, Robert Mark Van Veldhuizen ${ }^{1}$, Charles Winsett Knight ${ }^{2}$ \\ ${ }^{1}$ Agricultural and Forestry Experiment Station, University of Alaska Fairbanks, Fairbanks, USA \\ ${ }^{2}$ Division of Agriculture, Alaska Department of Natural Resources Division of Agriculture, Fairbanks, USA \\ Email: *mzhang3@alaska.edu
}

How to cite this paper: Cheng, M. Y., Zhang, M. C., Van Veldhuizen, R. M., \& Knight, C. W. (2021). Growing Season and Phenological Stages of Small Grain Crops in Response to Climate Change in Alaska. American Journal of Climate Change, 10, 490-511.

https://doi.org/10.4236/ajcc.2021.104025

Received: September 3, 2021

Accepted: December 18, 2021

Published: December 21, 2021

Copyright (c) 2021 by author(s) and Scientific Research Publishing Inc. This work is licensed under the Creative Commons Attribution International License (CC BY 4.0).

http://creativecommons.org/licenses/by/4.0/

\begin{abstract}
The climate change in Alaska has caused earlier spring snowmelt and the growing season expanded. However, the effect of climate change on crop phenological stages, heading (BBCH 55) and maturity (BBCH 85), is unknown. In this study, the trends of growing-season length (GSL), phenological stages of crops and climatic parameters, and the correlations between climatic parameters and the phenological stages were analyzed using the climate data and crop data over the period of 1978 to 2016. The longer GSL was found in Fairbanks $\left(64.83^{\circ} \mathrm{N}, 147.77^{\circ} \mathrm{W}\right)$ and in Delta Junction $\left(64.05^{\circ} \mathrm{N}, 145.60^{\circ} \mathrm{W}\right)$ but not in Palmer $\left(61.60^{\circ} \mathrm{N}, 149.11^{\circ} \mathrm{W}\right)$. Sowing dates did not change significantly in three locations. The decreasing trends of heading and maturity of crops were observed but varied with location. Heading of barley and oat significantly advanced 3 and $3.1 \mathrm{~d}$ decade $^{-1}$, respectively from 1989 to 2016 in Fairbanks while no change of heading was observed in Delta Junction and Palmer. Maturity of barley, oat and wheat significantly advanced 2.6, 3.8 and $3.9 \mathrm{~d}^{\text {decade }}{ }^{-1}$, respectively from 1978 to 2016 in Fairbanks $(P<0.05)$; maturity of oat and wheat significantly advanced 4.4 and $3.4 \mathrm{~d} \mathrm{decade}^{-1}$ from 1978 to 2015, respectively in Delta Junction $(P<0.05)$. The increasing temperature trends and decreasing precipitation trends were found in Fairbanks and Delta Junction but varied with phenological stages of crops. Sowing was more important for heading than for maturity of crops. The effect of climate change on heading was less important than that on maturity. Earlier maturity of crops in Fairbanks may be attributed to increased temperatures, that in Delta Junction to both increased minimum temperature and decreased precipitation and that in Palmer to temperature and precipitation.
\end{abstract}

\section{Keywords}

Heading, Maturity, Climate Change, Growing-Season Length, 
Growing Degree Days

\section{Introduction}

Plant phenology is a good indicator for climate change because weather parameters such as temperature, precipitation and photoperiod determine the growth and development of plants (Morison \& Morecroft, 2006). The correlation between plant phenology and climate change has been well documented based on the ground observations and satellite images. The ground observations have shown that warming temperature lengthens growing season (Hinzman et al., 2005; Khanduri et al., 2008), advances the unfolding of plant leaves (Menzel, 2000; Chmielewski \& Rötzer, 2001; Penuelas et al., 2002), and advances earlier flowering of plants (Bradley et al., 1999; Menzel, 2000; Abu-Asab et al., 2001; Penuelas et al., 2002). The satellite images have shown ice retreat in the high altitude and the expansion of the green cover (Jia \& Epstein, 2003; Kimball et al., 2006). These reports are from wild plants and the impacts of climate change on phenological stages of crops are also well documented (Tao et al., 2006; Xiao et al., 2013).

Understanding the impact of climate change on the phenology of field and fruit crops is of great economic importance. The effect of climate change on different phenological stages of field and fruit crops has been reported from many regions. In China, the analyses from observed field data show that warmer temperature advances the flowering and maturity dates of spring wheat (Triticumaestivum), winter wheat, early rice (Oryza sativa) (Tao et al., 2006; Xiao et al., 2013). In Germany, warmer temperature causes earlier start of growing season, earlier emergence and stem elongation, earlier flowering and harvest for winter rye (Secale cereal), and earlier flowering for cherry and apple (Malusdomestica) (Chmielewski et al., 2004). In France, the temperature anomalies over spring to summer are responsible for the earlier grape harvest (Chuine et al., 2004). In Finland, the regional anomalies cause the onset of the growing season and sowing of spring cereals earlier (Kaukoranta \& Hakala, 2008). In higher latitudes, there are some researches on the effect of climate change on the phenology of crops (Rötzer \& Chmielewski, 2001; Kaukoranta \& Hakala, 2008; Karlsen et al., 2009; Olesen et al., 2012) but there is not in Alaska.

Alaska, ranging from subarctic to arctic regions, is more sensitive to the climate changes than other places because of its high latitude, unique ecosystems and landscape characteristics (Shulski \& Wendler, 2007; Bieniek \& Walsh, 2014). The average annual summer temperature of Alaska increased by $1.9^{\circ} \mathrm{C}$ over the period 1949 to 2005 (Shulski \& Wendler, 2007). The rising temperature in Alaska has caused earlier spring snowmelt (Stone et al., 2002; Hinzman et al., 2005), lengthening of the growing season, greater growth of trees, and expansion of shrub tundra (Hinzman et al., 2005). However, how the warmer 
temperature affects the phonological development of agricultural crops in Alaska is unclear. The findings of climate changes in Alaska and their impacts on crop phenology may provide more useful information than those from other regions.

In Alaska, climate is one of the most important factors to affect crop planting, growing and harvesting. Currently, only a few field crops such as spring barley (Hordeumvulgare), spring oat (Avena sativa), spring wheat (Triticumaestivum L.), and potato (Solanumtuberosum) can be grown in Alaska because of harsh climate such as short growing season and low soil temperature although Alaska has a land of tremendous agricultural potential. The climate affects the crop growth at every growing stage (from sowing to harvesting). Among these growing stages, heading and maturity are two critical stages to affect the yields and determine whether the crop can adapt to the environment of Alaska. Therefore, the knowledge of the effect of climate change on the dates of heading and maturity of crops is of great importance for the agricultural decision makers, scientists and farmers on how to adapt to the change. The objectives of this paper were 1) to analyze the trends of Growing Season Length(GSL), climate parameters, and the observed phenology data of small grain crops from 1978 to 2016, 2) to determine the correlations between the climate change and phenological stages (heading and maturity), and 3) to determine heading and maturity variances explained by climate.

\section{Materials and Methods}

\subsection{Locations and Crop Data Including Sowing (BBCH 00), Heading (BBCH 55) and Maturity (BBCH 85)}

Fairbanks, Delta Junction and Palmer were chosen in this study because these regions are main locations to grow barley, oat and wheat in Alaska. In this study, the sowing, heading and maturity dates of spring barley, oat and wheat were obtained from the Alaska Alternative Crops Archives from 1978 to 2016 and preserved in Agricultural and Forestry Experiment Station of University of Alaska Fairbanks. The crop variety testing was carried out in the Experiment Farm of the University of Alaska Fairbanks $\left(64.83^{\circ} \mathrm{N}, 147.77^{\circ} \mathrm{W}\right)$, Delta Junction $\left(64.05^{\circ} \mathrm{N}\right.$, $\left.145.60^{\circ} \mathrm{W}\right)$ and Palmer $\left(61.60^{\circ} \mathrm{N}, 149.11^{\circ} \mathrm{W}\right)$ in Alaska. The varieties tested in trials were collected from Alaska, the western of United States (Idaho, Washington, North Dakota, Montana, Nebraska, Colorado, Illinois, and California) and the countries in the higher latitudes (especially from Canada, Sweden, Finland, Scotland, Germany, and Norway) and over 300 varieties have been tested (Van Veldhuizen et al., 2014). Heading of each variety was determined by the dates of $50 \%$ of spikes completely emerging from the boot (BBCH 55$)$ and those maturity by approximately $50 \%$ of spikes losing all green color (BBCH 85) (Dofing, 1995; Van Veldhuizen et al., 2014). The averaged heading and maturity dates of all varieties in each crop each year were used to represent the heading and maturity dates of the crop at that year. The heading dates of barley, oat and wheat were 
recorded from 1988 and the maturity dates of crops from 1978 in Fairbanks and Delta Junction. The records of heading and maturity of crops started from 1989 in Palmer (Table 1). However, there were no testing records for barley from 1993 to 1996 and 2011, no records for oat from 1990 to 1999 and 2011, and no records for wheat from 1990 to 1999, 2001, 2002 and 2011. Therefore, in Palmer the analysis on barley started from 1989 and on oat and wheat started from 2000.

\subsection{Climate Data}

In Alaska, daily minimum temperature and maximum temperature were used to forecast the timings of flowering and maturity of barley with the highest accuracy for flowering 100\% and for maturity $92 \%$ (Cheng \& Zhang, 2019). In addition, Sharratt et al. (2003) reported that precipitation was the important factor influencing small grain production and daily minimum temperature was a suboptimal factor for wheat production in Fairbanks. Therefore, to fully understand the effect of temperatures and precipitation on crop phenology, average temperature, minimum temperature, maximum temperature, diurnal temperature range, precipitation and $G D D$ were selected in this study. Daily average,

Table 1. Crops, phenological stages, testing periods and years in three locations of Alaska in this study.

\begin{tabular}{|c|c|c|c|c|}
\hline Locations & Crops & Phenological Stages & Periods & $\begin{array}{c}\text { Number of } \\
\text { Years }\end{array}$ \\
\hline \multirow{6}{*}{ Fairbanks } & \multirow{2}{*}{ Barleys } & Heading (BBCH 55) & $1988-2016$ & 29 \\
\hline & & Maturity (BBCH 85) & $1978-2016$ & 39 \\
\hline & \multirow{2}{*}{ Oats } & Heading (BBCH 55) & $1988-2016$ & 25 \\
\hline & & Maturity (BBCH 85) & $1978-2016$ & 35 \\
\hline & \multirow{2}{*}{ Wheats } & Heading (BBCH 55) & $1988-2016$ & 21 \\
\hline & & Maturity (BBCH 85) & $1978-2016$ & 31 \\
\hline \multirow{6}{*}{$\begin{array}{c}\text { Delta } \\
\text { Junction }\end{array}$} & \multirow[t]{2}{*}{ Barleys } & Heading (BBCH 55) & $1988-2015$ & 28 \\
\hline & & Maturity (BBCH 85) & $1978-2015$ & 38 \\
\hline & \multirow{2}{*}{ Oats } & Heading (BBCH 55) & $1988-2015$ & 25 \\
\hline & & Maturity (BBCH 85) & $1978-2015$ & 35 \\
\hline & \multirow{2}{*}{ Wheats } & Heading (BBCH 55) & $1988-2015$ & 25 \\
\hline & & Maturity (BBCH 85) & $1978-2015$ & 35 \\
\hline \multirow{6}{*}{ Palmer } & \multirow{2}{*}{ Barleys } & Heading (BBCH 55) & $1989-2016$ & 23 \\
\hline & & Maturity (BBCH 85) & $1989-2016$ & 23 \\
\hline & \multirow{2}{*}{ Oats } & Heading (BBCH 55) & $2000-2016$ & 14 \\
\hline & & Maturity (BBCH 85) & $2000-2016$ & 14 \\
\hline & \multirow{2}{*}{ Wheats } & Heading (BBCH 55) & $2000-2016$ & 14 \\
\hline & & Maturity (BBCH 85) & $2000-2016$ & 14 \\
\hline
\end{tabular}


maximum, and minimum temperatures, and precipitation were obtained from Data Tools: Local Climatological Data (LCD) of National Centers for Environmental Information (Young et al., 2018)

(https://www.ncdc.noaa.gov/cdo-web/datatools/lcd). The climate data of Fairbanks and Delta Junction were from 1978 to 2016 but those of Palmer from 1999 to 2016 because of the availability. The averages of average temperature $\left(T_{\text {arg }}\right)$, minimum temperature $\left(T_{\min }\right)$, and maximum temperature $\left(T_{\max }\right)$, diurnal temperature range $\left(T_{D T R}\right)$, cumulative precipitation $(C P)$ and $G D D$ over periodsfrom sowing to heading and from sowing to maturity were computed and used to analyze GSL, trends of crop phenology and climatic parameters, and correlation between crop phenology and climatic parameters. $G D D$ was calculated using the following formula:

$$
\mathrm{GDD}=\sum_{d_{1}}^{d_{2}}\left(\frac{T_{\text {Max }}-T_{\text {Min }}}{2}-T_{\text {base }}\right)
$$

where if $\frac{T_{M a x}-T_{M i n}}{2}<T_{\text {base }}$, then $\frac{T_{\text {Max }}-T_{\text {Min }}}{2}=T_{\text {base }} ; d_{1}$ is the sowing day and $d_{2}$ is the heading day or maturity day; $T_{\max }$ is daily maximum temperature, $T_{\min }$ is daily minimum temperature; $T_{\text {base }}$ is $5^{\circ} \mathrm{C}$ according to Hájková et al. (2019) because spring barley, oat and wheat in Alaska are cool season crops.

\subsection{Trends of Growing-Season Length (GSL)}

Growing-season length (GSL), the period from last spring date to first fall date, was of importance for agriculture. In this study, daily minimum air-temperature data from three locations (Fairbanks, Delta Junction and Palmer) were used to determine GSL. Specifically, the date of last spring (LS), date of first fall (FF), and the resulting GSL were determined using four threshold temperatures: $-4.4^{\circ} \mathrm{C}$, $-2.2^{\circ} \mathrm{C}, 0^{\circ} \mathrm{C}$, and $5.6^{\circ} \mathrm{C}$ because GSL determination based on the single threshold air temperature may cause misleading (Robeson, 2002). The other reason to select these four temperatures was that the first three represent freezing temperatures and $5.6^{\circ} \mathrm{C}$ was a climatic indicator for vegetables (Robeson, 2002). The trends in LS, FF and GSL were analyzed using linear regression methods of " $\mathrm{lm}$ " function in R (R Development Core Team, 2018). The threshold of p-value for the significance was $P<0.05$.

\subsection{Trends of Phenological Stages Including Sowing Date (BBCH 00), Heading Date (BBCH 55) and Maturity Date (BBCH 85) and Climatic Parameters}

The heading and maturity dates of three crops (barley, oat and wheat) in a year were the averaged dates of all cultivars of each crop tested at that year. Dates of sowing, heading, and maturity were transformed into the Julian days (day of year) in order to make the date as a continuous variable. Climatic parameters selected in this study were $T_{\text {avg }}, T_{\min }, T_{\max }, T_{D T R}, C P$ and $G D D$. The trends of time series of climatic parameters were analyzed by linear regression methods of " $1 \mathrm{~m}$ " function in R (R Development Core Team, 2018). The threshold of p-value for 
the significance was $P<0.05$.

\subsection{Correlations between Climatic Parameters and Dates of Heading, and between Climatic Parameters and Maturity}

In this study, the first-difference time series of heading $(\Delta H)$, maturity $(\Delta M)$ and climatic parameters $\left(\Delta T_{\text {arg }} \Delta T_{\min }, \Delta T_{\max } \Delta T_{D T R}, \Delta C P\right.$, and $\left.\triangle G D D\right)$ were computed using the equation $X_{\text {diff }}=X_{(t)}-X_{(t-1)}$ (where $t$ is the year, $t-1$ is the previous year and $t>1$ ) to reduce the confounding non-climatic effect (Lobell \& Field, 2007). The correlationsbetweenheading $(\Delta H)$ and climatic parameters $\left(\Delta T_{\text {avg }}\right.$, $\Delta T_{\min }, \Delta T_{\max } \Delta T_{D T R}, \Delta C P$ or $\left.\triangle G D D\right)$, and between maturity $(\Delta M)$ and climatic parameters $\left(\Delta T_{\text {avg }} \Delta T_{\text {min }}, \Delta T_{\max }, \Delta T_{D T R}, \Delta C P\right.$ or $\left.\triangle G D D\right)$ were analyzed using "cor.test" function in R (R Development Core Team, 2018). The threshold of p-value for the significance was $P<0.05$.

\subsection{The Variances of Heading and Maturity Explained by Climatic Parameters and Sowing}

$G D D$ is one of the widely used climate indexes for crop phenology. To investigate the uncertainty and the accountability between plant phenology (heading and maturity) and both climatic parameters and sowing, and the role of climatic parameters and sowing in heading and maturity, two linear regression models were fitted. In first model, $\triangle$ sowing, $\triangle G D D$ and $\triangle C P$ were used as independent variables and in the second model, $\triangle G D D$ and $\triangle C P$ were selected as independent variables and the linear regression models were fit as:

$$
\begin{gathered}
\Delta H \text { or } \Delta M=\beta_{0}+\beta_{1} \Delta \text { sowing }+\beta_{2} \Delta G D D+\beta_{3} \Delta C P+\varepsilon \\
\Delta H \text { or } \Delta M=\beta_{0}+\beta_{1} \Delta G D D+\beta_{2} \Delta C P+\varepsilon
\end{gathered}
$$

where $\triangle H$ or $\triangle M$ is the first-difference values of time series of heading dates or maturity dates; $\triangle$ sowing, $\triangle G D D$, and $\triangle C P$ are the first-difference values of time series of sowing and climatic parameters; $\beta_{0-3}$ are coefficients which represent the sensitivity of heading and maturity to sowing, $G D D$ and $C P, \varepsilon$ is the error. In order to determine the importance of the variables, all the variables used in above equations were standardized by using the "scale" function in R ( R Development Core Team, 2018). The models were fit using the "lm" function and the best fit models were selected using the "stepAIC" function in the "MASS" package from the full model in R (R Development Core Team, 2018).

\section{Results}

\subsection{Date of Last Spring (LS), Date of First Fall (FF) and Growing Season Length (GSL)}

The trends of LS, FF, and GSL were determined using four minimum temperature $\left(T_{\min }\right)$ degrees $\left(-4.4^{\circ} \mathrm{C},-2.2^{\circ} \mathrm{C}, 0^{\circ} \mathrm{C}\right.$ and $\left.5.6^{\circ} \mathrm{C}\right)$ as critical thresholds. The results from linear regression analysis showed that spring became warmer, advancing 3.8 ddecade $^{-1}$ in Fairbanks and $2.6 \mathrm{~d} \mathrm{decade}^{-1}$ in Delta Junction with $5.6^{\circ} \mathrm{C}$ as a threshold $(P<0.01)$, respectively. GSL was 5.3 days longer per decade 
when $5.6^{\circ} \mathrm{C}$ as a threshold $(P<0.05)$ from 1978 to 2016 in Fairbanks while in Delta Junction, GSL became $5.7 \mathrm{~d}$ per decade longer when $5.6^{\circ} \mathrm{C}$ as a threshold from 1978 to $2015(P<0.05)$ (Table 2). The trends of GSL in Palmer were different from those in both Fairbanks and Delta Junction. In Palmer, spring, fall and GSL did not change significantly from 1999 to 2016 at all four temperature thresholds $(P<0.05)$ (Table 2$)$.

\subsection{Trends of Sowing, Flowering, and Maturity}

\subsubsection{Trend of Sowing}

Linear regression analyses of sowing dates from three locations showed that there were no significantly linear increasing or decreasing trends for the sowing dates at Fairbanks, Delta Junction and Palmer $(P>0.05)$ (Figure 1).

Table 2. Estimated linear trends (days year ${ }^{-1}$ ) for last spring (LS), first fall date (FF), and growing-season length (GSL) for three locations in Alaska (using $-4.4^{\circ} \mathrm{C},-2.2^{\circ} \mathrm{C}, 0^{\circ} \mathrm{C}$ and $5.6^{\circ} \mathrm{C}$ as the critical $T_{\min }$ thresholds).

\begin{tabular}{cccccccccccccc}
\hline Location & Year & $\begin{array}{c}\text { LS44 } \\
\text { trend }\end{array}$ & $\begin{array}{c}\text { LS22 } \\
\text { trend }\end{array}$ & $\begin{array}{c}\text { LS0 } \\
\text { trend }\end{array}$ & $\begin{array}{c}\text { LS56 } \\
\text { trend }\end{array}$ & $\begin{array}{c}\text { FF44 } \\
\text { trend }\end{array}$ & $\begin{array}{c}\text { FF22 } \\
\text { trend }\end{array}$ & $\begin{array}{c}\text { FF0 } \\
\text { trend }\end{array}$ & $\begin{array}{c}\text { FF56 } \\
\text { trend }\end{array}$ & $\begin{array}{c}\text { GSL44 } \\
\text { trend }\end{array}$ & $\begin{array}{c}\text { GSL22 } \\
\text { trend }\end{array}$ & $\begin{array}{c}\text { GSL0 } \\
\text { trend }\end{array}$ & $\begin{array}{c}\text { GSL56 } \\
\text { trend }\end{array}$ \\
\hline Fairbanks & $1978-2016$ & 0.17 & 0.03 & 0.08 & $-0.38^{* *}$ & -0.16 & 0.04 & 0.27 & 0.15 & -0.33 & 0.007 & 0.19 & $0.53^{*}$ \\
Delta & $1978-2015$ & -0.05 & 0.015 & -0.08 & $-0.26^{*}$ & 0.01 & 0.14 & 0.27 & 0.31 & 0.06 & 0.12 & 0.35 & $0.57^{* *}$ \\
Palmer & $1999-2016$ & -0.10 & -0.62 & -0.30 & 0.008 & -0.37 & -0.50 & 0.12 & -0.20 & -0.27 & 0.12 & 0.42 & -0.20 \\
\hline
\end{tabular}

Note: ${ }^{\star}$ indicates $P<0.05 ;{ }^{\star *}$ indicates $P<0.01$. Negative (positive) trends in SF indicate warming (cooling), while negative (positive) trends in FF and GSL indicate cooling (warming).

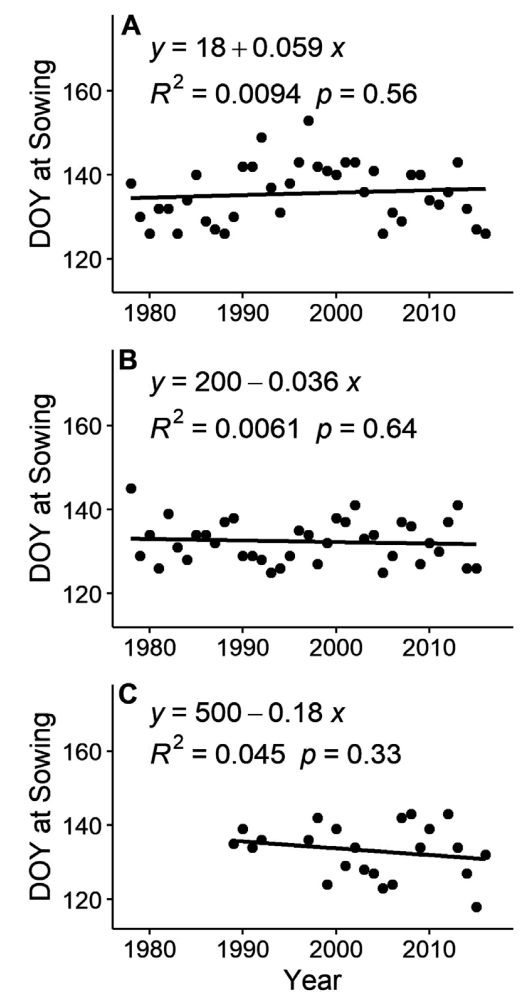

Figure 1. Linear regression trends for sowing date (GS 00) in three regions in Alaska. (A) Fairbanks (1978 - 2016), (B) Delta Junction (1978 - 2016), and (C) Palmer (1989 - 2016). $P<0.05$ indicates significant. DOY, day of the year. 


\subsubsection{Trends of Heading and Maturity}

The decreasing heading trends were observed but varied with crop and location. For barley, the heading date significantly advanced $2.5 \mathrm{~d}_{\text {decade }}{ }^{-1}$ in Fairbanks $(P<0.05)$ (Figure $2(\mathrm{~A}))$ while there were no significant changes in heading in Delta Junction and Palmer (Figure 3(A) and Figure 4(A)). For oat, the heading date advanced $3.1 \mathrm{~d}^{\text {decade }}{ }^{-1}$ in Fairbanks (Figure 2(C)) while no significant changes in the timing of heading were observed in Delta Junction and Palmer (Figure $3(C)$ and Figure $4(C)$ ). The heading timing of wheat remained the same in three locations (Figure 2(E), Figure 3(E) and Figure 4(E)).

The results of maturity trends showed that barley matured significantly early only in Fairbanks $\left(2.6 \mathrm{~d} \mathrm{decade}^{-1}\right)(P<0.05)$ (Figure 2(B)); oat significantly matured $3.8 \mathrm{~d}^{\text {decade }}{ }^{-1}$ early in Fairbanks $(P<0.01)$ (Figure $\left.2(\mathrm{D})\right)$ and $4.4 \mathrm{~d}$ decade $^{-1}$ early in Delta Junction $(P<0.01)$ (Figure $\left.3(D)\right)$, respectively; wheat matured significantly $3.9 \mathrm{~d}^{\text {decade }}{ }^{-1}$ in Fairbanks $(P<0.01)$ (Figure $2(\mathrm{~F})$ ) and $3.4 \mathrm{~d} \mathrm{decade}^{-1}$ in Delta Junction $(P<0.05)$ (Figure $\left.3(\mathrm{~F})\right)$, respectively.
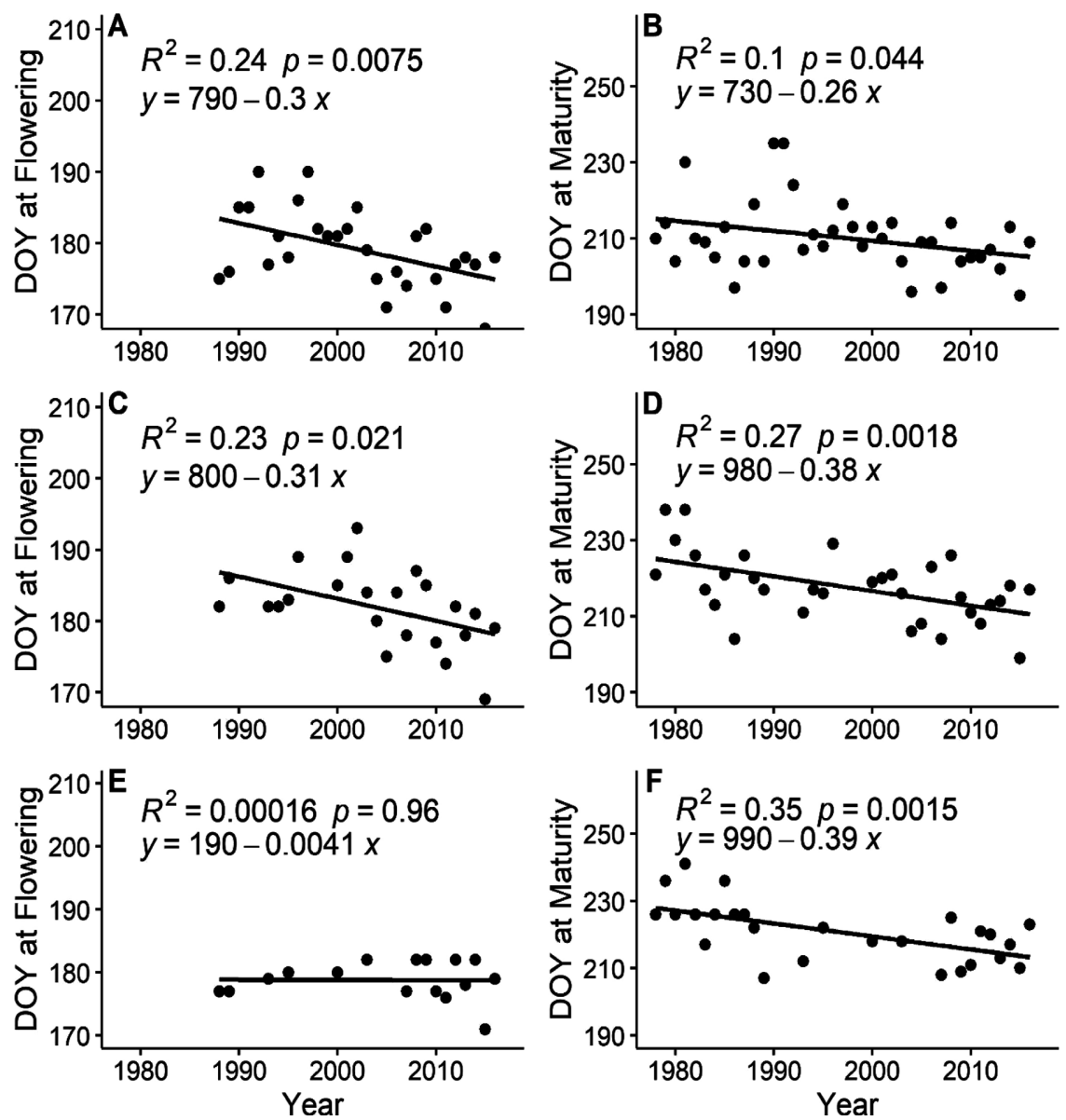

Figure 2. Linear regression trends for heading date (GS 55) and maturity date (GS 85) of small grain crops in Fairbanks, Alaska from 1978 to 2016. (A) heading date of barley, (B) maturity date of barley, (C) heading date of oat, (D) maturity date of oat, (E) heading date 0 wheat, and (F) maturity date of wheat. $P<0.05$ indicates significant. DOY, day of the year. 

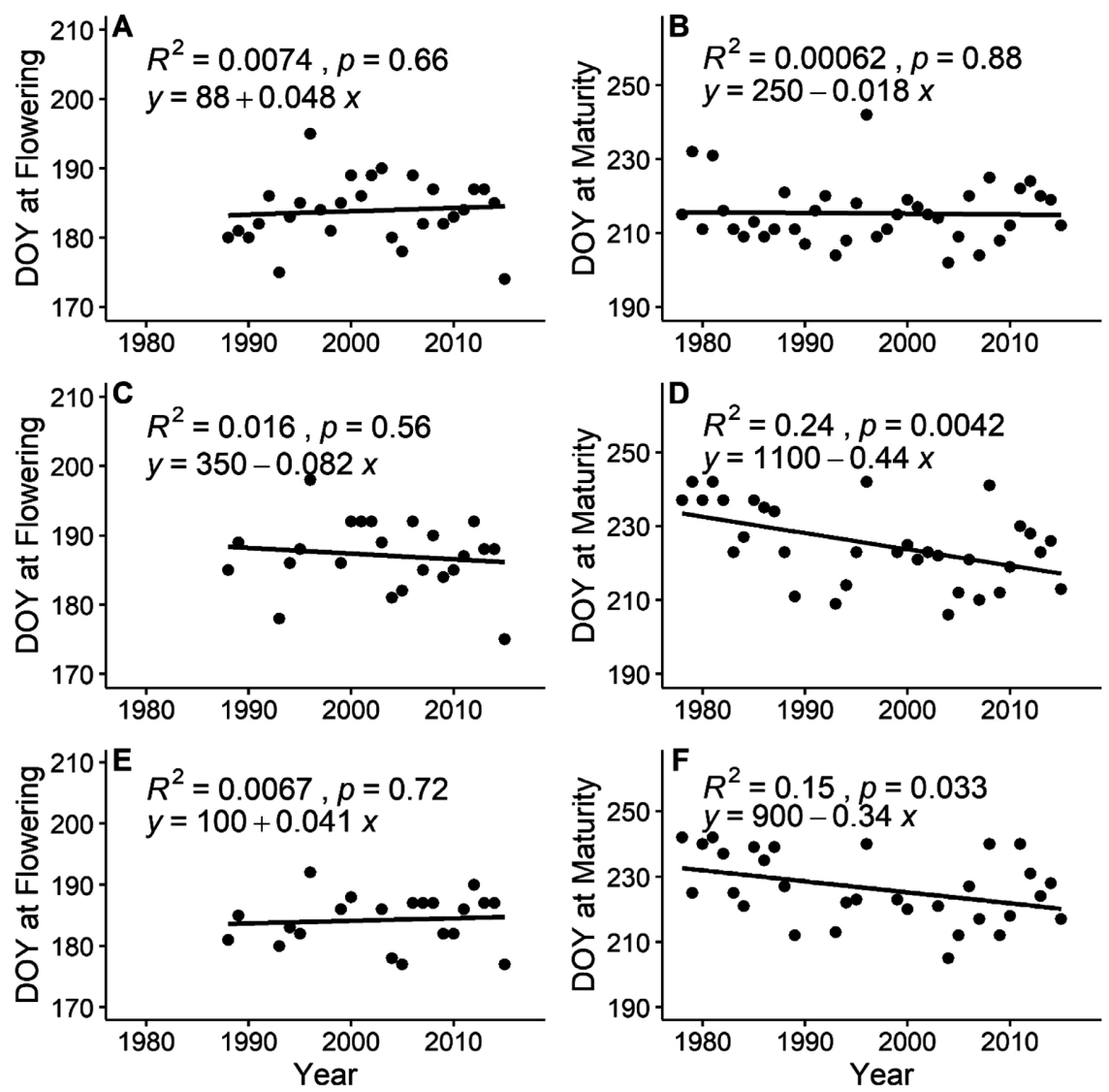

Figure 3. Linear regression trends for heading date (GS 55) and maturity date (GS 85) of small grain crops in Delta Junction, Alaska from 1978 to 2016. (A) heading date of barley, (B) maturity date of barley, (C) heading date of oat, (D) maturity date of oat, (E) heading date of wheat, and (F) maturity date of wheat. $P<0.05$ indicates significant. DOY, day of the year.

\subsection{Trends of Climate Parameters and Relationship with the Timings of Heading and Maturity in Three Regions of Alaska}

\subsubsection{Trends of $T_{\max }, T_{\min }, T_{\mathrm{avg}}, T_{D T R}, C P$ and $G D D$}

The trends of $T_{\max } T_{\min }, T_{\text {arg }} T_{D T R}, C P$ and $G D D$ over the period from sowing to heading varied with location and crop (Table 3). No $T_{\max } T_{\text {avg }}$ and $C P$ trends were observed in three crops in three locations. Increasing $T_{\min }$ and decreasing $T_{D T R}$ trends were observed in three crops only in Delta Junction. $G D D$ significantly decreased $2.2^{\circ} \mathrm{C} \mathrm{d} \mathrm{yr}^{-1}$ in oat in Fairbanks $(P<0.05)$.

More increasing $T_{\min }$ and $T_{\text {avg }}$ trends and decreasing $C P$ trends over the period from sowing to maturity were observed than over the period from sowing to heading $(P<0.05)$ (Table 3). $T_{\min }$ increased in three crops in Fairbanks $\left(0.03^{\circ} \mathrm{C}\right.$ $\mathrm{yr}^{-1}$ increasing for barley and wheat maturity, and $0.04^{\circ} \mathrm{C} \mathrm{yr}^{-1}$ increasing for oat maturity). $T_{\text {arg }}$ significantly increased $0.03^{\circ} \mathrm{C} \mathrm{yr}^{-1}$ in three crops only in Fairbanks. $C P$ decreased $0.18 \mathrm{~cm} \mathrm{yr}^{-1}$ in oatand $0.17 \mathrm{~cm} \mathrm{yr}^{-1}$ in Delta Junction.

\subsubsection{Correlations between Climatic Parameters and Flowering and Maturity}

In general, temperatures $\left(T_{\max }, T_{\min }, T_{\text {avg }}\right.$ and $\left.T_{D T R}\right)$ were negatively but $G D D$ 

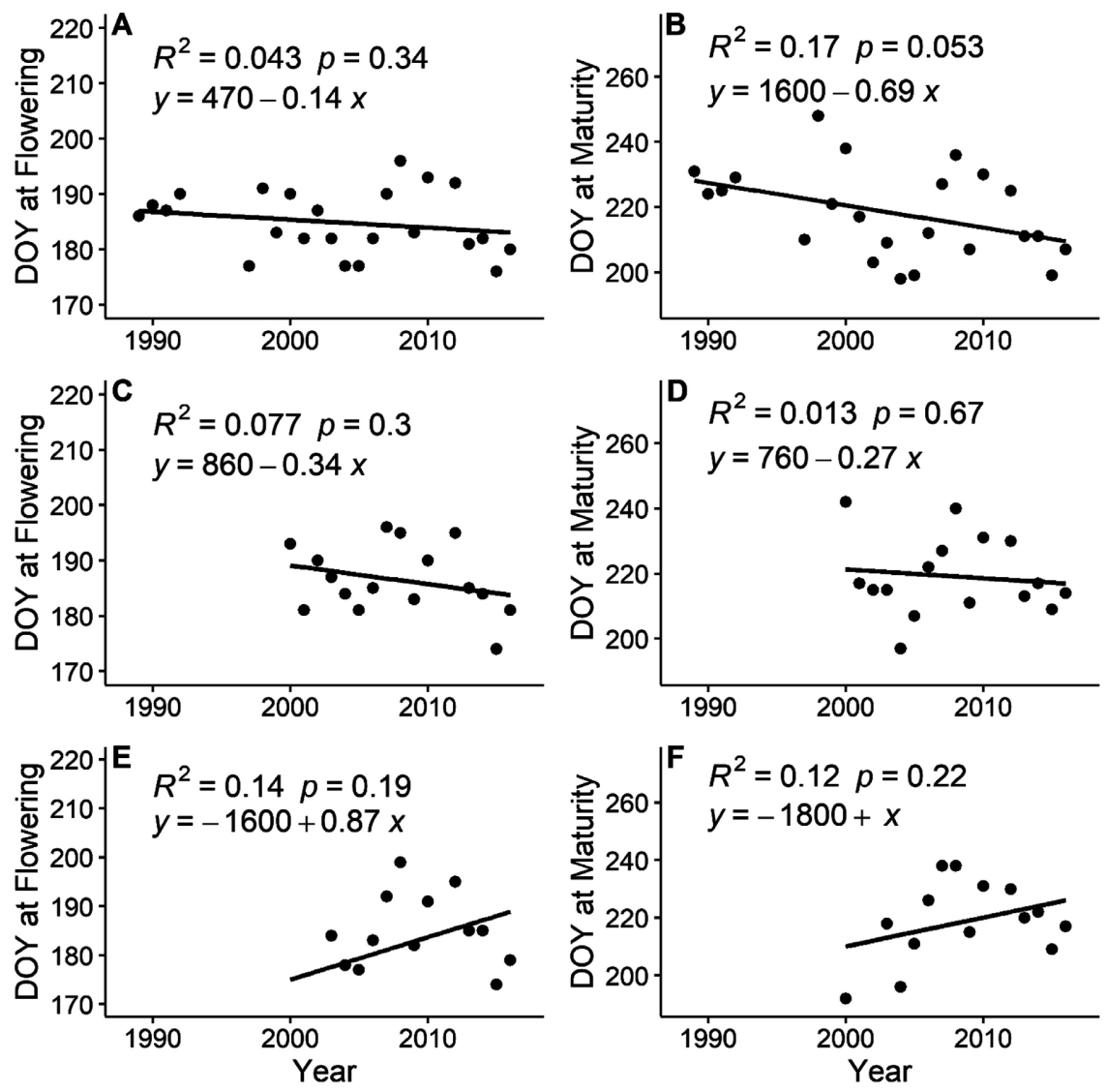

Figure 4. Linear regression trends for heading date (GS 55) and maturity date (GS 85) of small grain crops in Palmer, Alaska from 1989 to 2016. (A) heading date of barley, (B) maturity date of barley, (C) heading date of oat, (D) maturity date of oat, (E) heading date of wheat, and (F) maturity date of wheat. $P<0.05$ indicates significant. DOY, day of the year.

and $C P$ positively correlated with heading and maturity. The correlations were higher between climatic parameters and maturity than those between climatic parameters and heading. In Fairbanks, $T_{\min }$ and $T_{\text {avg }}$ were not significantly correlated with the heading dates and the maturity dates of three crops $(P<0.05)$; $T_{D T R}$ was negatively correlated with wheat heading dates and with the maturity dates of barley, oat, and wheat $(P<0.05)$; $C P$ was positively correlated with oat flowering date $(P<0.01)$; GDD was positively correlated with the maturity date of barley and oat $(P<0.01)$ (Table 4$)$. In Delta Junction, $T_{\min }$ was negatively correlated with the heading of barley and oat; $T_{D T R}$ was negatively correlated with oat heading; $C P$ was positively correlated with the heading dates of barley and oat $(P<0.05)$; for the timings of maturity, all correlation coefficients were significant except the correlations between $T_{D T R}$ and barley maturity, and between $G D D$ and the maturity dates of oat and wheat $(P<0.05)$ (Table 4$)$. In Palmer, $T_{\min }$, and $T_{D T R}$ were significantly correlated with heading of three crops (Table 4), $T_{\max }$ and $T_{D T R}$ and $C P$ were significantly correlated with maturity of crops and $G D D$ were significantly correlated with maturity of barley and oat $(P<$ 0.05) (Table 4). 
Table 3. Estimated linear trends of temperature $\left({ }^{\circ} \mathrm{C} \mathrm{yr}^{-1}\right)$, precipitation $\left(\mathrm{cm} \mathrm{yr}^{-1}\right)$ and $G D D\left({ }^{\circ} \mathrm{C} \mathrm{d} \mathrm{yr} r^{-1}\right)$ in three locations. $T_{\max }, T_{\min }, T_{\text {avg }}, T_{\text {DTR }}, C P$ and $G D D$ are the time series of average maximum temperature, average minimum temperature, average temperature, average diurnal temperature range, cumulative precipitation and growing degree days over the period from sowing to heading or from sowing to maturity.

\begin{tabular}{|c|c|c|c|c|c|}
\hline \multirow{2}{*}{ Crop } & \multirow{2}{*}{ Period } & \multirow{2}{*}{$\begin{array}{c}\text { Temperature } \\
\text { and rain }\end{array}$} & \multicolumn{3}{|c|}{ Location } \\
\hline & & & Fairbanks & Delta Junction & Palmer \\
\hline \multirow{12}{*}{ Barley } & \multirow{6}{*}{$\begin{array}{l}\text { Sowing to } \\
\text { heading }\end{array}$} & $T_{\max }$ & -0.02 & -0.02 & 0.05 \\
\hline & & $T_{\min }$ & -0.02 & $0.07^{\star *}$ & 0.03 \\
\hline & & $T_{a v g}$ & -0.02 & 0.03 & 0.04 \\
\hline & & $T_{D T R}$ & -0.007 & $-0.09^{\star \star}$ & 0.01 \\
\hline & & $C P$ & -0.05 & 0.02 & 0.008 \\
\hline & & $G D D$ & -1.53 & 1.32 & 0.99 \\
\hline & \multirow{6}{*}{$\begin{array}{l}\text { Sowing to } \\
\text { maturity }\end{array}$} & $T_{\max }$ & 0.03 & 0.001 & 0.06 \\
\hline & & $T_{\min }$ & $0.03^{*}$ & 0.02 & 0.03 \\
\hline & & $T_{\text {avg }}$ & $0.03^{\star}$ & 0.01 & 0.05 \\
\hline & & $T_{D T R}$ & -0.004 & -0.02 & 0.02 \\
\hline & & $C P$ & 0.06 & -0.08 & -0.11 \\
\hline & & $G D D$ & -1.06 & 0.85 & 0.005 \\
\hline \multirow{12}{*}{ Oat } & \multirow{6}{*}{$\begin{array}{c}\text { Sowing to } \\
\text { heading }\end{array}$} & $T_{\max }$ & 0.02 & -0.02 & 0.06 \\
\hline & & $T_{\min }$ & 0.01 & 0.04 & 0.004 \\
\hline & & $T_{a v g}$ & 0.02 & 0.01 & 0.03 \\
\hline & & $T_{D T R}$ & 0.001 & $-0.07^{\star}$ & 0.05 \\
\hline & & $C P$ & -0.08 & -0.05 & 0.05 \\
\hline & & $G D D$ & $-2.20^{\star}$ & 0.50 & -1.48 \\
\hline & \multirow{6}{*}{$\begin{array}{l}\text { Sowing to } \\
\text { maturity }\end{array}$} & $T_{\max }$ & 0.03 & 0.01 & 0.08 \\
\hline & & $T_{\min }$ & $0.04^{\star *}$ & 0.02 & 0.04 \\
\hline & & $T_{a v g}$ & $0.03^{\star}$ & 0.02 & 0.06 \\
\hline & & $T_{D T R}$ & -0.005 & -0.007 & 0.03 \\
\hline & & $C P$ & 0.06 & $-0.18^{\star}$ & -0.06 \\
\hline & & $G D D$ & -2.15 & -2.09 & 2.69 \\
\hline \multirow{12}{*}{ Wheat } & \multirow{6}{*}{$\begin{array}{l}\text { Sowing to } \\
\text { heading }\end{array}$} & $T_{\max }$ & 0.05 & -0.009 & 0.06 \\
\hline & & $T_{\min }$ & 0.03 & $0.06^{\star}$ & 0.004 \\
\hline & & $T_{a v g}$ & 0.04 & 0.03 & 0.03 \\
\hline & & $T_{D T R}$ & 0.02 & $-0.07^{\star}$ & 0.05 \\
\hline & & $C P$ & -0.01 & -0.05 & 0.05 \\
\hline & & $G D D$ & 0.93 & 1.96 & 0.65 \\
\hline & \multirow{6}{*}{$\begin{array}{l}\text { Sowing to } \\
\text { maturity }\end{array}$} & $T_{\max }$ & 0.03 & 0.01 & 0.08 \\
\hline & & $T_{\min }$ & $0.03^{\star *}$ & 0.02 & 0.04 \\
\hline & & $T_{a v g}$ & $0.03^{\star}$ & 0.02 & 0.06 \\
\hline & & $T_{D T R}$ & -0.001 & -0.008 & 0.03 \\
\hline & & $C P$ & 0.10 & $-0.17^{\star}$ & -0.06 \\
\hline & & $G D D$ & -1.92 & -0.87 & 3.24 \\
\hline
\end{tabular}

${ }^{\star}$ Indicates $P$-value $<0.05 ;{ }^{\star *} P$-value $<0.01$. Minus indicates negative effect and plus indicates positive effect. 
Table 4. Correlation coefficients between heading and climatic parameters, between maturity and climatic parameters. $\Delta H$, and $\Delta M$ are the first-difference values of time series of heading and maturity. $\Delta T_{\text {avg }}, \Delta T_{\min }, \Delta T_{\max }, \Delta T_{\mathrm{DTR}}, \triangle C P$ and $\triangle G D D$ are the first-difference values of time series of average temperature, average minimum temperature, average maximum temperature, average diurnal temperature range, cumulative precipitation and growing degree days over the period from sowing to heading or from sowing to maturity.

\begin{tabular}{|c|c|c|c|c|c|c|c|}
\hline \multirow{2}{*}{ Locations } & \multirow{2}{*}{$\begin{array}{c}\text { Climatic } \\
\text { parameters }\end{array}$} & \multicolumn{3}{|c|}{$\Delta H$} & \multicolumn{3}{|c|}{$\Delta M$} \\
\hline & & Barley & Oat & Wheat & Barley & Oat & Wheat \\
\hline \multirow{6}{*}{ Fairbanks } & $\Delta T_{\max }$ & 0.15 & -0.28 & -0.47 & -0.25 & $-0.39^{*}$ & $-0.43^{*}$ \\
\hline & $\Delta T_{\min }$ & 0.23 & -0.08 & -0.23 & 0.15 & -0.15 & -0.21 \\
\hline & $\Delta T_{\mathrm{avg}}$ & 0.19 & -0.21 & -0.41 & -0.07 & -0.32 & -0.38 \\
\hline & $\Delta T_{\mathrm{DTR}}$ & -0.07 & -0.35 & $-0.51^{\star}$ & $-0.58^{\star * *}$ & $-0.47^{\star \star}$ & $-0.47^{\star}$ \\
\hline & $\triangle C P$ & 0.27 & 0.37 & 0.41 & $0.64^{* * *}$ & $0.45^{\star \star}$ & $0.58^{\star *}$ \\
\hline & $\Delta G D D$ & 0.37 & 0.31 & -0.14 & $0.72^{\star * *}$ & $0.52^{\star *}$ & 0.30 \\
\hline \multirow{6}{*}{$\begin{array}{c}\text { Delta } \\
\text { Junction }\end{array}$} & $\Delta T_{\max }$ & $-0.40^{\star}$ & $-0.47^{\star}$ & -0.42 & $-0.50^{\star *}$ & $-0.65^{\star * *}$ & $-0.62^{\star * *}$ \\
\hline & $\Delta T_{\min }$ & -0.26 & -0.16 & -0.3 & $-0.50^{\star *}$ & $-0.61^{\star * *}$ & $-0.53^{\star \star}$ \\
\hline & $\Delta T_{\mathrm{avg}}$ & -0.37 & -0.36 & -0.41 & $-0.53^{\star * *}$ & $-0.66^{\star * *}$ & $-0.6^{\star * *}$ \\
\hline & $\Delta T_{\mathrm{DTR}}$ & -0.37 & $-0.58^{\star *}$ & -0.36 & -0.27 & $-0.39^{*}$ & $-0.46^{*}$ \\
\hline & $\triangle C P$ & $0.38^{\star}$ & $0.51^{\star}$ & 0.34 & $0.61^{\star * *}$ & $0.58^{\star * *}$ & $0.39^{\star}$ \\
\hline & $\triangle G D D$ & 0.02 & -0.009 & -0.32 & $0.47^{\star *}$ & 0.09 & 0.19 \\
\hline \multirow{6}{*}{ Palmer } & $\Delta T_{\max }$ & -0.2 & -0.13 & -0.37 & $-0.59^{*}$ & $-0.67^{\star \star}$ & $-0.57^{\star}$ \\
\hline & $\Delta T_{\min }$ & $0.7^{\star *}$ & $0.73^{\star *}$ & $0.63^{\star}$ & 0.36 & 0.08 & 0.11 \\
\hline & $\Delta T_{\text {avg }}$ & 0.19 & 0.28 & 0.07 & -0.31 & $-0.52^{\star}$ & -0.4 \\
\hline & $\Delta T_{\mathrm{DTR}}$ & $-0.65^{\star *}$ & $-0.64^{\star}$ & $-0.75^{\star \star}$ & $-0.8^{\star * *}$ & $-0.74^{\star *}$ & $-0.71^{\star *}$ \\
\hline & $\triangle C P$ & 0.3 & 0.22 & 0.4 & $0.66^{* *}$ & $0.65^{* *}$ & $0.59^{*}$ \\
\hline & $\triangle G D D$ & 0.14 & 0.23 & 0.28 & $0.60^{\star}$ & $0.54^{\star}$ & 0.47 \\
\hline
\end{tabular}

Values represent the correlation coefficients. Minus indicates negative correlation and plus positive correlation. ${ }^{*}$ indicates $P$-value $<0.05 ;{ }^{* *} P$-value $<0.01 ;{ }^{* *} P$-value $<0.001$.

\subsection{Roles of GDD, CP and Sowing for Heading and Maturity, Variances Explained by Climate Parameters and Sowing}

The best fit models showed heading can be better explained by sowing, $G D D$ and $C P$ than by climate parameters ( $G D D$ and $C P$ ) (Table 5). The $\mathrm{R}^{2}$ of models derived from $\triangle$ sowng, $\triangle G D D$, and $\triangle C P$ was almost double the one from $\triangle G D D$ and $\triangle C P$, with $0.57-0.60$ vs $0.17-0.25$ in Fairbanks, $0.30-0.47$ vs $0.12-0.26$ in Delta Junction and $0.66-0.81$ vs $0.22-0.38$ in Palmer (Table 5). The models also showed that early sowing, and decreased $C P$ caused early heading of all crops in three locations. $G D D$ was positively correlated to the heading except $G D D$ of oat in Fairbanks and $G D D$ of wheat in Delta Junction (Table 5). The estimated parameter of sowing was bigger than that of $G D D$ or $C P$ except those for barley and oat in Delta Junction (Table 5). GDD were important for heading in 
Table 5. Regression parameter estimates of the best models to predict $\triangle H$ from $\triangle$ sowing, $\triangle G D D$ and $\triangle C P$ or from $\triangle G D D$ and $\triangle C P . \Delta F, \triangle$ sowing, $\triangle G D D$, and $\triangle C P$ are the first-difference values of time series of heading, sowing, growth degree days and cumulative precipitation over period from sowing to heading. The best fitted model is derived from $\Delta H=\beta_{0}+\beta_{1} \Delta$ sowing + $\beta_{2} \Delta G D D+\beta_{3} \Delta C P+\mathcal{E}(2)$ or $\Delta F=\beta_{0}+\beta_{1} \Delta G D D+\beta_{2} \Delta C P+\varepsilon(3)$.

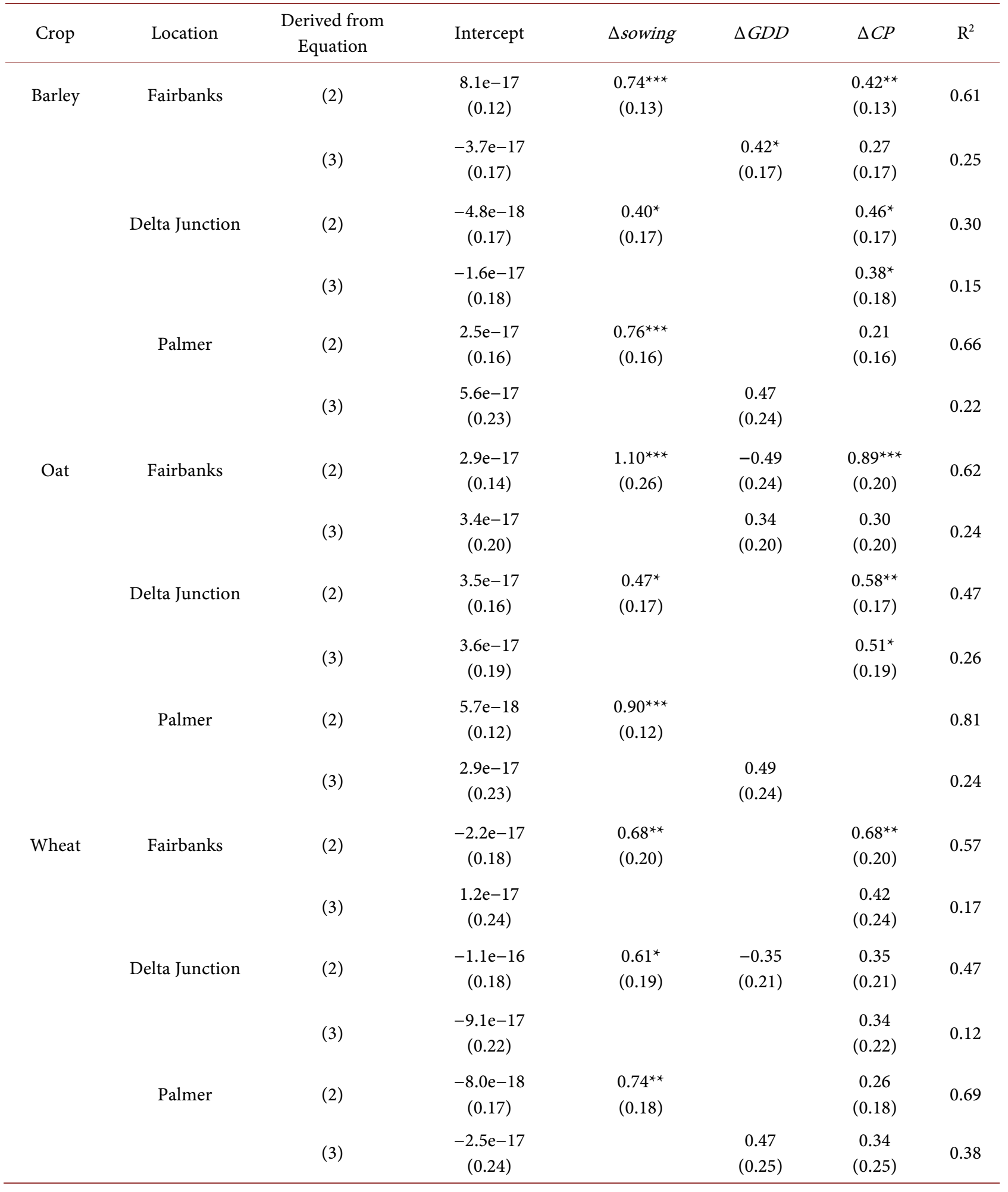

Note: the number in parentheses is standard error; ${ }^{*}$ indicates $P$-value $<0.05 ;{ }^{* *}$ indicates $P$-value $<0.01$; ${ }^{* * *}$ indicates $P$-value $<$ 0.001 . 
Fairbanks and Palmer while $C P$ was important for heading in Delta Junction because heading can be explained by $C P$ alone.

The best fit models showed that maturity explained by sowing, $G D D$ and $C P$ was similar to that explained by $G D D$ and $C P$ based on the values of $\mathrm{R}^{2}$ (Table 6). The $\mathrm{R}^{2}$ values from five of 18 models were higher than 0.5 (Table 6). The

Table 6. Regression parameter estimates of the best models to predict $\triangle M$ from $\triangle$ sowing, $\triangle G D D$ and $\triangle C P$ or from $\triangle G D D$ and $\triangle C P . \Delta M, \triangle$ sowing, $\triangle G D D$, and $\triangle C P$ are the first-difference values of time series of maturity, sowing, growth degree days and cumulative precipitation over period from sowing to maturity. The best fitted model is derived from: $\Delta M=\beta_{0}+\beta_{1} \Delta$ sowing + $\beta_{2} \Delta G D D+\beta_{3} \Delta C P+\varepsilon(2)$ or $\Delta M=\beta_{0}+\beta_{1} \Delta G D D+\beta_{2} \Delta C P+\varepsilon(3)$.

\begin{tabular}{|c|c|c|c|c|c|c|c|}
\hline Crop & Location & Derived from Equation & Intercept & $\Delta$ sowing & $\triangle G D D$ & $\triangle C P$ & $\mathrm{R}^{2}$ \\
\hline \multirow[t]{6}{*}{ Barley } & \multirow[t]{2}{*}{ Fairbanks } & $(2)$ & $\begin{array}{c}4.5 e-17 \\
(0.09)\end{array}$ & $\begin{array}{c}0.19 \\
(0.09)\end{array}$ & $\begin{array}{c}0.50^{\star * *} \\
(0.11)\end{array}$ & $\begin{array}{c}0.43^{* * *} \\
(0.11)\end{array}$ & 0.69 \\
\hline & & (3) & $\begin{array}{c}5.7 e-17 \\
(0.10)\end{array}$ & & $\begin{array}{c}0.56^{\star * *} \\
(0.11)\end{array}$ & $\begin{array}{c}0.40^{\star * *} \\
(0.11)\end{array}$ & 0.66 \\
\hline & \multirow[t]{2}{*}{ Delta Junction } & $(2)$ & $\begin{array}{c}-6.3 e-17 \\
(0.12)\end{array}$ & & $\begin{array}{l}0.37^{\star *} \\
(0.12)\end{array}$ & $\begin{array}{c}0.57^{\star * *} \\
(0.12)\end{array}$ & 0.51 \\
\hline & & (3) & $\begin{array}{c}-6.3 e-17 \\
(0.12)\end{array}$ & & $\begin{array}{l}0.37^{\star *} \\
(0.12)\end{array}$ & $\begin{array}{c}0.57^{\star * *} \\
(0.12)\end{array}$ & 0.51 \\
\hline & \multirow[t]{2}{*}{ Palmer } & $(2)$ & $\begin{array}{c}4.7 e-17 \\
(0.16)\end{array}$ & $\begin{array}{c}0.36 \\
(0.19)\end{array}$ & $\begin{array}{c}0.30 \\
(0.20)\end{array}$ & $\begin{array}{l}0.44^{\star} \\
(0.18)\end{array}$ & 0.71 \\
\hline & & (3) & $\begin{array}{c}4.7 e-17 \\
(0.17)\end{array}$ & & $\begin{array}{l}0.47^{\star} \\
(0.20)\end{array}$ & $\begin{array}{l}0.46^{*} \\
(0.20)\end{array}$ & 0.61 \\
\hline \multirow[t]{6}{*}{ Oat } & \multirow[t]{2}{*}{ Fairbanks } & $(2)$ & $\begin{array}{c}5.0 \mathrm{e}-17 \\
(0.12)\end{array}$ & $\begin{array}{l}0.29^{\star} \\
(0.13)\end{array}$ & $\begin{array}{c}0.48^{\star * *} \\
(0.13)\end{array}$ & $\begin{array}{c}0.54^{\star * *} \\
(0.13)\end{array}$ & 0.57 \\
\hline & & (3) & $\begin{array}{c}4.4 \mathrm{e}-17 \\
(0.13)\end{array}$ & & $\begin{array}{c}0.55^{\star * *} \\
(0.13)\end{array}$ & $\begin{array}{l}0.47^{\star *} \\
(0.13)\end{array}$ & 0.50 \\
\hline & \multirow[t]{2}{*}{ Delta Junction } & $(2)$ & $\begin{array}{c}4.9 e-17 \\
(0.15)\end{array}$ & & & $\begin{array}{c}0.58^{\star * *} \\
(0.15)\end{array}$ & 0.33 \\
\hline & & (3) & $\begin{array}{c}4.9 \mathrm{e}-17 \\
(0.15)\end{array}$ & & & $\begin{array}{c}0.58^{\star * *} \\
(0.15)\end{array}$ & 0.33 \\
\hline & Palmer & $(2)$ & $\begin{array}{c}1.7 e-17 \\
(0.17)\end{array}$ & $\begin{array}{c}0.41 \\
(0.19)\end{array}$ & & $\begin{array}{l}0.56^{*} \\
(0.19)\end{array}$ & 0.59 \\
\hline & \multirow{3}{*}{ Fairbanks } & (3) & $\begin{array}{c}4.4 \mathrm{e}-17 \\
(0.18)\end{array}$ & & $\begin{array}{c}0.41 \\
(0.21)\end{array}$ & $\begin{array}{l}0.47^{\star} \\
(0.21)\end{array}$ & 0.56 \\
\hline \multirow[t]{6}{*}{ Wheat } & & $(2)$ & $\begin{array}{c}1.5 \mathrm{e}-16 \\
(0.12)\end{array}$ & $\begin{array}{l}0.43^{\star *} \\
(0.12)\end{array}$ & $\begin{array}{l}0.41^{\star *} \\
(0.12)\end{array}$ & $\begin{array}{c}0.63^{\star * *} \\
(0.12)\end{array}$ & 0.67 \\
\hline & & (3) & $\begin{array}{c}1.2 \mathrm{e}-16 \\
(0.15)\end{array}$ & & $\begin{array}{l}0.39^{\star} \\
(0.15)\end{array}$ & $\begin{array}{c}0.57^{\star * *} \\
(0.15)\end{array}$ & 0.49 \\
\hline & \multirow[t]{2}{*}{ Delta Junction } & $(2)$ & $\begin{array}{c}-1.4 \mathrm{e}-17 \\
(0.15)\end{array}$ & $\begin{array}{c}0.26 \\
(0.16)\end{array}$ & $\begin{array}{l}0.42^{*} \\
(0.17)\end{array}$ & $\begin{array}{c}0.59^{* * *} \\
(0.17)\end{array}$ & 0.37 \\
\hline & & (3) & $\begin{array}{c}8.5 e-18 \\
(0.16)\end{array}$ & & $\begin{array}{l}0.42^{*} \\
(0.17)\end{array}$ & $\begin{array}{l}0.54^{* *} \\
(0.17)\end{array}$ & 0.30 \\
\hline & \multirow[t]{2}{*}{ Palmer } & (2) & $\begin{array}{c}-4.4 \mathrm{e}-17 \\
(0.19)\end{array}$ & $\begin{array}{c}0.42 \\
(0.21)\end{array}$ & $\begin{array}{c}0.29 \\
(0.21)\end{array}$ & $\begin{array}{c}0.39 \\
(0.21)\end{array}$ & 0.66 \\
\hline & & (3) & $\begin{array}{c}-1.7 e-17 \\
(0.21)\end{array}$ & & $\begin{array}{c}0.41 \\
(0.23)\end{array}$ & $\begin{array}{c}0.48 \\
(0.23)\end{array}$ & 0.50 \\
\hline
\end{tabular}

Note: the number in parentheses is standard error; ${ }^{*}$ indicates $P$-value $<0.05 ;{ }^{* *}$ indicates $P$-value $<0.01 ;{ }^{* *}$ indicates $P$-value $<$ 0.001 . 
roles of $G D D$ and $C P$ for maturity were more important than that of sowing, with the estimated parameter coefficients of sowing smaller than that of $G D D$ or $C P$ (the only exception was the maturity of wheat in Palmer) (Table 6). In Fairbanks, $G D D$ was more important than $C P$ while $C P$ was more important than $G D D$ in Delta Junction and Palmer (Table 6).

\section{Discussion}

\subsection{Growing Season Length (GSL) and Its Impact on the Sowing Date, Alaska Future Agriculture and Comparison with Scandinavian and Fennoscandia Countries}

\subsubsection{Growing Season Length and Sowing in Fairbanks and Delta Junction}

The early start of the growing season resulted in significant advancement in sowing of spring cereals in the west of Finland (Kaukoranta \& Hakala, 2008). In this study, the growing-season in Fairbanks and Delta Junction from 1978 to 2016 became longer based on the analyses of SF, FF, and GSL when $5.6^{\circ} \mathrm{C}$ was used as a threshold. However, in this study the longer growing-season did not result in sowing earlier because the sowing trends in Fairbanks and Delta Junction was not statistically significant (Figure 1). One reason is that sowing dates from variety trials were different from real farm fields and are influenced by human decision. In addition, temperature is not the only factor to affect the sowing dates and some other possible factors such as the soil condition (i.e., too wet), precipitation, preparations (such as seed, equipment, and fertilizer), and crop management decisions may affect the sowing dates of variety trials.

\subsubsection{The Effect of Growing Season Length (GSL) on Agriculture of Alaska}

The length of the growing season increased $45 \%$ from 85 to 123 days during the period between 1906 and 2006 in Fairbanks, Alaska (Wendler \& Shulski, 2009). The results in this study showed that GSL in Fairbanks and Delta Junction increased more than 20 days in the last four decades when $5.6^{\circ} \mathrm{C}$ was used as a temperature threshold. The $5.6^{\circ} \mathrm{C}$ is higher than the base temperature $\left(5^{\circ} \mathrm{C}\right)$ for oat and wheat to grow (Slafer \& Rawson, 1995; Olesen et al., 2012), suggesting that the suitable growing season for oat and wheat have been extended since 1980's in Fairbanks and Delta Junction. Therefore, the varieties released in the 1980's and currently used in testing and production in Alaska may not be suitable for the extended growing season and new late-maturing varieties should be developed or introduced to cope with the GSL extension.

\subsubsection{Comparison of Growing Season between Alaska and Scandinavian or Fennoscandia Countries}

Alaska and Scandinavia (Denmark, Norway and Sweden) or Fennoscandia (Norway, Sweden, Finland and parts of Russia) are all in higher latitudes of the Northern Hemisphere and are affected by climate changes more than other regions. However, the length of growing season is different between Alaska and 
Scandinavian or Fennoscandia countries. The growing season in Alaska is shorter than that in Denmark and the southern part of Sweden but same as in Northern Norway (Rötzer \& Chmielewski, 2001). For example, the average growing season is 110 days for Fairbanks, 94 days for Delta Junction and 144 days for Palmer. The growing season in Denmark and in the southern part of Sweden is $180-200$ days (Rötzer \& Chmielewski, 2001), and that in Northern Norway 90 - 180 days (Uleberg et al., 2014).

\subsection{Impacts of Climate on Heading (BBCH 55) and Maturity (BBCH 85)}

Both temperature and precipitation are the major climatic parameters to impact the growth and flowering of crops (Morison \& Morecroft, 2006; Tao et al., 2006). Warmer temperature advances the timing of crop flowering (Tao et al., 2006; Xiao et al., 2013; He et al., 2015). However, there are only a few reports on the effect of climate on crop heading dates. A significant negative heading trend is found across West Germany for the period 1972-2013 but increased temperature only explained half of the observed trend and another half explained by sowing dates and cultivar (Rezaei et al., 2018). The significantly advanced heading dates of spring wheat (cv. Thatcher) from 1950 to 2007 in Montana, USA, are attributed to earlier sowing dates because of increased temperature in March and photoperiod sensitive cultivar "Thatcher" (Lanning et al., 2010). These results agree with the findings in this study that climate may playsome limited roles in heading of crops in Alaska because $G D D$ and $C P$ only can explained half of the variances of heading than sowing, $G D D$, and $C P$ (Table 5). Meanwhile, based on the linear models of this study, sowing had a greater influence on the heading dates than climate factors ( $G D D$ and $C P$ ), confirming the previous report that sowing is highly correlated with barley flowering and is the most important factor to predict flowering of barley flowering in Alaska (Cheng \& Zhang, 2019).

In general, crops mature earlier because of warmer temperatures and reduced precipitation (Tao et al., 2006), agreeing with the findings in this study that temperature and precipitation played an important role for crop maturity in Alaska. Based on the results from $G D D$ and $C P$ models, the trends of climate parameters and correlations between climatic parameters and crop maturity, the earlier maturity of barley, oat and wheat in Fairbanks may be attributed to the warmer temperatures; both temperature and $C P$ may be responsible for earlier maturity of oat and wheat in Delta Junction; temperature and $C P$ may be responsible for the maturity change in Palmer.

\subsection{Effect of Variety Shift on Heading and Maturity Dates of Crops}

The variety shift of small grain crops tested in Alaska may affect timings of heading and maturity at a certain year and may also affect the trends of heading and maturity in this study. The purpose of variety trials of small grain crops is to select the most suitable crops to grow in Alaska. The selected criteria for the varieties tested in Alaska are early maturity, high yield and quality, and adaptation 
to a particular geographic location (Van Veldhuizen \& Knight, 2004). The majority of varieties tested in the trial would be rejected after one or two years based on their performances compared with those of standard varieties which have consistently performed well at a given geographic location over several years (Van Veldhuizen et al., 2014). Some standard varieties (Otal, Datal, Weal, Thual, Athabasca, Cascade, Nip, Toral, Ingal, Nogal and Roblin) have been tested in the trials and used in production since the beginning of 1980's in Alaska. Because the selection of new varieties is based on the standard varieties tested in the trial every year, the maturity of tested varieties may belong to the category of the standard varieties, and the heading dates and the maturity dates of newly introduced varieties may not be far from those of the standard varieties. Thus, the averaged dates of heading and maturity of all varieties tested at a certain year may be used to represent the heading and maturity dates of the crops at that year. Meanwhile, the long-term test trials (nearly 40 years) in Fairbanks and Delta Junction may offset or reduce the bias caused by some varieties in a certain year. However, the number of varieties tested in the trials has been reduced in recent years and some standard varieties (such as Galt, Otra, Pendek, Rodney, Chena, Gasser, and Park) have been changed and not used in the testing and production anymore (Van Veldhuizen et al., 2014). Therefore, the crop variety shift in testing trials in Alaska may play some roles in impacting crop heading and maturity as previously reported (He et al., 2015; Rezaei et al., 2018). In order to provide more useful information for Alaskan breeding and production, further research using standard varieties is needed to determine how the crop flowering and maturity are affected by the variety shift.

\subsection{Adaptation to Temperature and Precipitation Changes in Alaska}

The warmer temperature has negative impacts on the phenological stage of crops and yields (Tao et al., 2006). The historical climate data in Alaska indicated that Alaska began warming up in the last century (Shulski \& Wendler, 2007) and this trend will continue in the future. The findings in this study suggest that the warmer temperature extends the length of growing season suitable for barley, oat and wheat, and the warmer temperature and reduced precipitation advance the heading and maturity of barley, oat and wheat at least one week. Therefore, in order to cope with the temperature increase and advancement of crop maturity, new later ripening varieties with higher yield should be developed, introduced, or tested in variety trials in Alaska.

Precipitation is another important climate factor to impact crop phenology and yield (Lobell et al., 2011; Luo et al., 2018). Previously research showed that precipitation in Fairbanks decreased 11\% from 1916 to 2006 but is not statistically significant (Wendler \& Shulski, 2009) and it agrees with the findings in this study that there is no statistically significant change in precipitation from 1978 to 2016 in Fairbanks. However, the findings in this study indicate that the precipitation during the growing season in Delta Junction decreased statistically sig- 
nificantly. In general, precipitation in Fairbanks and Delta Junction is scarce. The increased temperature and decreased precipitation may cause the occurrence of droughts more likely although the precipitation may not be a great risk to Alaska in the near future. Therefore, the policy makers should pay attention to regions like Delta Junction in order to adapt to the shortage of precipitation. The possible solutions for precipitation decreasing may include finding new water resources, investing on irrigation infrastructure and selecting drought resistant varieties.

Climate change in Alaska and its effect on agriculture is evident over the past 39 years according to this study. Based on the climate change from the period of 1981 to 2010 , daily $T_{\min }$ and $T_{\max }$ are projected to increase $6.8^{\circ} \mathrm{C}$ and $7^{\circ} \mathrm{C}$ in summer months (June-July-August) by 2100, respectively (Lader et al., 2017). The spring cultivation will potentially occur 2 - 4 weeks earlier and the statewide average GSL is projected to be 50 days longer than now by the end of the century (Lader et al., 2018). In Fairbanks days with $T_{\text {avg }}>25^{\circ} \mathrm{C}$ are anticipated to happen 5 - 10 times per year by 2100 (rarely happens now) (Lader et al., 2018) and precipitation to increase $61 \%$ by 2100 (Lader et al., 2017). The temperatures around Anchorage (40 miles from Palmer) are projected to be less affected but the precipitation is expected to increase $49 \%$ by 2100 (Lader et al., 2017). These projections and the results from this study suggest that the crop production in Alaska will play an increasingly important role in the United States. The cropping system should be changed from now to cope with climate change in the next 30 years or a century. The cropping system changes could include the following. First, the types of crops should be increased. The crops that had been tested in Alaska since the 1970s included barley, oat, wheat, buckwheat, flax, field pea, canola and sun-flower. Currently, only barley, oat and wheat are grown across Alaska. It is projected that other crops currently tested in the trial may become main crops in the future. In addition, based on the temperature increase and extended growing season in Alaska, the crops, such as maize and others grown in northern part of the United States and other circumpolar countries, which cannot be grown in Alaska now, should be introduced and tested in Alaska because the increased temperature and longer growing season will satisfy the needed growing degree-days of these crops. Second, cultivars should deploy according to the locations. For example, some cultivars may still be planted in the Palmer area in the near future because of less change in climate. Third, farmers should be encouraged to try new crops with high yield and high market value and should provide information and suggestions to breeders for what they need to grow. Fourth, warmer temperatures will bring some benefits for agriculture in Alaska (such as yield) but it will also bring some risks such as pests and diseases (Stevenson et al., 2014). Therefore, the research on identification of pests and plant pathogens, and their management practices should be started now. Lastly, a crop simulation model should be established and updated regularly by including new crops and climate parameters to better guide Alaska agricultural production (Rötter et al., 2011). 


\section{Conclusion}

Based on analyses of climate and crop data in Alaska, the growing-season extension is due to advanced last freeze-free days in spring and delayed first freeze-free days in fall. Sowing had more impact on the heading time than on the maturity time. The roles of temperature and precipitation playing on heading changes are less important than on maturity in Fairbanks and Delta Junction. The early maturity of crops in Fairbanks may be mostly attributed to increased temperature and in Delta Junction may be attributed to increased temperature and reduced precipitation. The results in this study imply that Alaska agriculture will expand in the future due to extended growth season length and increased temperature, and the varieties currently used in production need to be changed to adapt to climate change.

\section{Acknowledgements}

The research is funded by USDA Hatch project ALK 19-04 and Multi state project ALK 15-03.We thank all the researchers who did not list as co-authors from University of Alaska Fairbanks for their great contributions to Alaska Small Grain Alternative Crop Testing Trials. These researchers include late Dr. Frank J. Wooding, Dr. Carol Lewis, Dr. Jenifer H. McBeath, Dr. Stephen M. Dofing, Dr. George A. Michel Jr., Dr. Brenton Sharratt, S. Frost, J. T. Hanscon and G. M. Delucchi. We are also grateful to the anonymous reviewers and editor for their insightful comments on the earlier version of this manuscript.

\section{Conflicts of Interest}

No conflicts of interest regarding the publication of the study.

\section{References}

Abu-Asab, M. S., Peterson, P. M., Shetler, S. G., \& Orli, S. S. (2001). Earlier Plant Flowering in Spring as a Response to Global Warming in the Washington, DC, Area. Biodiversity and Conservation, 10, 597-612. https://doi.org/10.1023/A:1016667125469

Bieniek, P. A., \& Walsh, J. E. (2014). Using Climate Divisions to Analyze Variation and Trends in Alaska Temperature and Precipitation. Journal of Climate, 27, 2800-2818. https://doi.org/10.1175/JCLI-D-13-00342.1

Bradley, N. L., Leopold, A. C., Ross, J., \& Huffaker, W. (1999). Phenology Changes Reflect Climate Change in Wisconsin. Proceedings of the National Academy of Sciences of the United States of America, 96, 9701-9704. https://doi.org/10.1073/pnas.96.17.9701

Cheng, M., \& Zhang, M. (2019). Forecasting Flowering and Maturity Times of Barley Using Six Machine Learning Algorithms. Journal of Agricultural Science and Technology B, 9, 373-391. https://doi.org/10.17265/2161-6264/2019.06.002

Chmielewski, F. M., \& Rötzer, T. (2001). Response of Tree Phenology to Climate Changes across Europe. Agricultural and Forest Meteorology, 108, 101-112. https://doi.org/10.1016/S0168-1923(01)00233-7

Chmielewski, F. M., Müller, A., \& Bruns, E. (2004). Climate Changes and Trend in Phenology of Fruit Trees and Field Crops in Germany, 1961-2000. Agricultural and Forest Meteorology, 121, 69-78. https://doi.org/10.1016/S0168-1923(03)00161-8 
Chuine, I., Yiou, P., Viovy, N., Seguin, B., Daux, V., \& Ladurie, E. L. R. (2004). Historical Phenology: Grape Ripening as a Past Climate Indicator. Nature, 432, 289-290. https://doi.org/10.1038/432289a

Dofing, S. M. (1995). Phenological Development-Yield Relationships in Spring Barley in a Subarctic Environment. Canadian Journal of Plant Science, 75, 93-97.

https://doi.org/10.4141/cjps95-015

Hájková, L., Možný, M., Kožnarová, V., Bartošová, L., \& Žalud, Z. (2019). Relationship between Phenological and Meterorological Data as an Important Input into Spring Barley Phenological Model. Acta Universitatis Agriculturae et Silviculturae Mendelianae Brunensis, 67, 679-688. https://doi.org/10.11118/actaun201967030679

He, L., Asseng, S., Zhao, G., Wu, D., Yang, X., Zhuang, W., Jin, N., \& Yu, Q. (2015). Impacts of Recent Climate Warming, Cultivar Changes, and Crop Management on Winter Wheat Phenology across the Loess Plateau of China. Agricultural and Forest Meteorology, 200, 135-143. https://doi.org/10.1016/j.agrformet.2014.09.011

Hinzman, L. D., Bettez, N. D., Bolton, W. R., Chapin, F. S. et al. (2005). Evidence and Implications of Recent Climate Change in Northern Alaska and Other Arctic Regions. Climatic Change, 72, 251-298. https://doi.org/10.1007/s10584-005-5352-2

Jia, G. J., \& Epstein, H. E. (2003). Greening of Arctic Alaska, 1981-2001. Geophysical Research Letters, 30, Article No. 2067. https://doi.org/10.1029/2003GL018268

Karlsen, S. R., Høgda, K. A., Wielgolaski, F. E., Tolvanen, A., Tømmervik, H., Poikolainen, J., \& Kubin, E. (2009). Growing-Season Trend in Fennoscandia 1982-2006, Determined from Satellite and Phenology Data. Climatic Research, 39, 275-286.

https://doi.org/10.3354/cr00828

Kaukoranta, T., \& Hakala, K. (2008). Impact of Spring Warming on Sowing Times of Cereal, Potato and Sugar Beet in Finland. Agricultural and Food Science, 17, 165-176. https://doi.org/10.2137/145960608785328198

Khanduri, V. P., Sharma, C. M., \& Singh, S. P. (2008). The Effects of Climate Change on Plant Phenology. The Environmentalist, 28, 143-147. https://doi.org/10.1007/s10669-007-9153-1

Kimball, J. S., McDonald, K. C., \& Zhao, M. (2006). Spring Thaw and Its Effect on Terrestrial Vegetation Productivity in the Western Arctic Observed from Satellite Microwave and Optical Remote Sensing. Earth Interactions, 10, 1-22. https://doi.org/10.1175/EI187.1

Lader, R., Walsh, J. E., Bhatt, U. S., \& Bieniek, P. A. (2017). Projections of Twenty-FirstCentury Climate Extremes for Alaska via Dynamical Downscaling and Quantile Mapping. Journal of Applied Meteorology Climatology, 56, 2393-2409. https://doi.org/10.1175/JAMC-D-16-0415.1

Lader, R., Walsh, J. E., Bhatt, U. S., \& Bieniek, P. A. (2018). Agro-Climate Projections for a Warming Alaska. Earth Interactions, 22, 1-24.

https://doi.org/10.1175/EI-D-17-0036.1

Lanning, S. P., Kephart, K., Carlson, G. R., Eckhoff, J. E., Stougaard, R. N., Wichman, D. M., Martin, J. M., \& Talbert, L. E. (2010). Climatic Change and Agronomic Performance of Hard Red Spring Wheat from 1950 to 2007. Crop Science, 50, 835-841. https://doi.org/10.2135/cropsci2009.06.0314

Lobell, D. B., \& Field, C. B. (2007). Global Scale Climate-Crop Yield Relationships and the Impacts of Recent Warming. Environmental Research Letters, 2, Article ID: 014002. https://doi.org/10.1088/1748-9326/2/1/014002

Lobell, D. B., Schlenker,W., \& Costa-Roberts, J. (2011). Climate Trends and Global Crop Production since 1980. Science, 333, 616-620. https://doi.org/10.1126/science.1204531 
Luo, Q., O’Leary, G., Cleverly, J., \& Eamus, D. (2018). Effectiveness of Time of Sowing and Cultivar Choice for Managing Climate Change: Wheat Crop Phenology and Water Use Efficiency. International Journal of Biometeorology, 62, 1049-1061. https://doi.org/10.1007/s00484-018-1508-4

Menzel, A. (2000). Trends in Phenological Phases in Europe between 1951 and 1996. International Journal of Biometeorology, 44, 76-81. https://doi.org/10.1007/s004840000054

Morison, J. I. L., \& Morecroft, M. D. (2006). Plant Growth and Climate Change. WileyBlackwell, 232 p. https://doi.org/10.1002/9780470988695

Olesen, J. E., Børgesen, C. D., Elsgaard, L., Palosuo, T., Rötter, R. P., Skjelvåg, A. O., Peltonen-Sainio, P., Börjesson, T., Trnka, M., Ewert, F., Siebert, S., Brisson, N., Eitzinger, J., van Asselt, E. D., Oberforster, M., \& van der Fels-Klerx., H. J. (2012). Change in Time of Sowing, Flowering and Maturity of Cereals in Europe under Climate Change. Food Additives \& Contaminants: Part A, 29, 1527-1542. https://doi.org/10.1080/19440049.2012.712060

Penuelas, J., Filella, I., \& Comas, P. (2002). Changed Plants and Animal Cycles from 1952 to 2000 in the Mediterranean Region. Global Change Biology, 8, 531-544. https://doi.org/10.1046/j.1365-2486.2002.00489.x

R Development Core Team (2018). R: A Language and Environment for Statistical Computing. R Foundation for Statistical Computing. https://www.R-project.org/

Rezaei, E. E., Siebert, S., Hüging, H., \& Ewart, F. (2018). Climate Change Effect on Wheat Phenology Depends on Cultivar Change. Scientific Reports, 8, Article No. 4891. https://doi.org/10.1038/s41598-018-23101-2

Robeson, S. M. (2002). Increasing Growing-Season Length in Illinois during the 20th Century. Climatic Change, 52, 219-238. https://doi.org/10.1023/A:1013088011223

Rötter, R. P., Palosuo, T., Pirttioja, N. K., Dubrovsky, M., Salo, T., Fronzek, S., Aikasalo, R., Trnka, M., Ristolainen, A., \& Carter, T. R. (2011). What Would Happen to Barley Production in Finland if Global Warming Exceeded $4^{\circ} \mathrm{C}$ ? A Model-Based Assessment. European Journal of Agronomy, 35, 205-214. https://doi.org/10.1016/j.eja.2011.06.003

Rötzer, T., \& Chmielewski, F. M. (2001). Phenological Maps of Europe. Climatic Research, 18, 249-257. https://doi.org/10.3354/cr018249

Sharratt, B. S., Knight, C. W., \& Wooding, F. (2003). Climatic Impact on Small Grain Production in the Subarctic Region of the United States. Arctic, 56, 219-226. https://doi.org/10.14430/arctic617

Shulski, M., \& Wendler, G. (2007). The Climate of Alaska. University of Alaska Press.

Slafer, G. A., \& Rawson, H. M. (1995). Base and Optimum Temperatures Vary with Genotype and Stage of Development in Wheat. Plant, Cell \& Environment, 18, 671-679. https://doi.org/10.1111/j.1365-3040.1995.tb00568.x

Stevenson, K. T., Rader, H. B., Alessa, L., Kliskey, A. D., Pantoja, A., Clark, M., \& Smeek, J. (2104). Sustainable Agriculture for Alaska and the Circumpolar North: Part II. Environmental, Geophysical, Biological and Socioeconomic Challenges. Arctic, 67, 296-319. https://doi.org/10.14430/arctic4408

Stone, R. S., Dutton, E. G., Harris, J. M., \& Longenecker, D. (2002). Earlier Spring Snowmelt in Northern Alaska as an Indicator of Climate Change. Journal of Geophysical Research, 107, 4089. https://doi.org/10.1029/2000JD000286

Tao, F., Yokozawa, M., Xu, Y., Hayashi, Y., \& Zhang, Z. (2006). Climate Changes and Trend in Phenology and Yields of Field Crops in China, 1981-2000. Agricultural and Forest Meteorology, 138, 82-92. https://doi.org/10.1016/j.agrformet.2006.03.014 
Uleberg, E., Hanssen-Bauer, I., van Oort, B., \& Dalmannsdottir, S. (2014). Impact of Climate Change on Agriculture in Northern Norway and Potential Strategies for Adaption. Climatic Change, 122, 27-39. https://doi.org/10.1007/s10584-013-0983-1

Van Veldhuizen, R. M., \& Knight, C. W. (2004). Performance of Agronomic Crop Varieties in Alaska 1978-2002. AFES Bulletin 111. Agriculture and Foresty Experiment Station, University of Alaska Fairbanks, $136 \mathrm{p}$.

http://afesresearch.uaf.edu/publications/?\&s $=* \& \mathrm{pt}=* \& \mathrm{cat}=23$

Van Veldhuizen, R. M., Zhang, M., \& Knight, C. W. (2014). Performance of Agronomic Crop Varieties in Alaska 1978-2012. AFES Bulletin 116. Agriculture and Forestry Experiment Station, University of Alaska Fairbanks, $252 \mathrm{p}$.

http://afesresearch.uaf.edu/publications/?\&s $={ }^{*} \& p t=*$ $=23$

Wendler, G., \& Shulski, M. (2009). A Century of Climate Change for Fairbanks, Alaska. Arctic, 62, 295-300. https://doi.org/10.14430/arctic149

Xiao, D., Tao, F., Liu, Y., Shi, W., Wang, M., Liu, F., Zhang, S., \& Zhu, Z. (2013). Observed Changes in Winter Wheat Phenology in the North China Plain for 1981-2009. International Journal of Biometeorology, 57, 275-285.

https://doi.org/10.1007/s00484-012-0552-8

Young, A. H., Knapp, K. R., Inamdar, A., Hankins, W., \& Rossow, W. B. (2018). The International Satellite Cloud Climatology Projection H-Series Climate Data Record Product. Earth System Science Data, 10, 583-593.

https://doi.org/10.5194/essd-10-583-2018 